\title{
Bacteria Detection at a Single-Cell Level through a Cyanotype-Based Photochemical Reaction
}

\author{
Jiri Dietvorst, Amparo Ferrer-Vilanova, Sharath Narayana Iyengar, Aman Russom, Núria Vigués, \\ Jordi Mas, Lluïsa Vilaplana, Maria-Pilar Marco, Gonzalo Guirado,* and Xavier Muñoz-Berbel**
}

Cite This: Anal. Chem. 2022, 94, 787-792

Read Online

ACCESS | Lلll Metrics \& More | 回 Article Recommendations | S1 Supporting Information

ABSTRACT: The detection of living organisms at very low concentrations is necessary for the early diagnosis of bacterial infections, but it is still challenging as there is a need for signal amplification. Cell culture, nucleic acid amplification, or nanostructure-based signal enhancement are the most common amplification methods, relying on long, tedious, complex, or expensive procedures. Here, we present a cyanotype-based photochemical amplification reaction enabling the detection of low bacterial concentrations up to a single-cell level. Photocatalysis is induced with visible light and requires bacterial metabolism of iron-based compounds to produce Prussian Blue. Bacterial activity

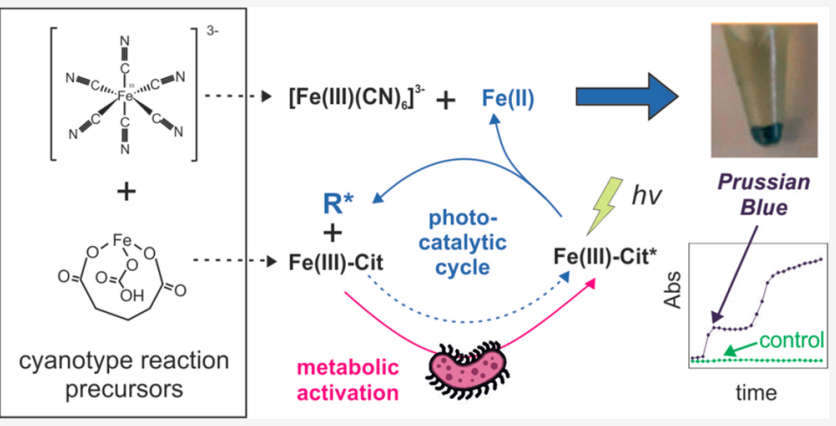
is thus detected through the formation of an observable blue precipitate within $3 \mathrm{~h}$ of the reaction, which corresponds to the concentration of living organisms. The short time-to-result and simplicity of the reaction are expected to strongly impact the clinical diagnosis of infectious diseases.

\section{INTRODUCTION}

Bacteria are microorganisms related to important healthcare and safety problems including infectious diseases, ${ }^{1}$ food poisoning, ${ }^{2}$ and water pollution. ${ }^{3}$ Lower respiratory infections and diarrheal diseases are now positioned as the fourth and eighth cause of death worldwide. ${ }^{4}$ Diarrheal diseases, resulting from the consumption of contaminated food and water, are estimated to cause 550 million foodborne illnesses and 230000 deaths every year, where Escherichia coli is one of the most common foodborne pathogens. ${ }^{5}$ To minimize the impact of bacterial infections, these microorganisms should be detected at an early stage of infection, when only a few bacteria are present. This is particularly important in the case of sepsis, requiring the detection of less than 100 colony forming units $(\mathrm{CFU}) / \mathrm{mL}$ in the bloodstream, ${ }^{6}$ since every hour delay in the detection of bacteria increases patients' mortality by $10 \%{ }^{7}$

Current gold standard methods for microbial detection involve amplification steps to reach the appropriate bacteria detectability. The three most common amplification methods are: (i) pre-enrichment by cell culture, where bacterial proliferation increases cell population up to a detectable magnitude; (ii) nucleic acid amplification, such as the polymerase chain reaction (PCR), ${ }^{9}$ where a specific target sequence is copied many times in repeated cycles until reaching a detectable number of copies; and (iii) nanostructure-based signal enhancement, e.g., surface-enhanced Raman spectroscopy (SERS), where a Raman scattering signal is amplified by the use of nanoscale roughness features that increase its sensitivity up to a single bacterium level. ${ }^{10}$ However, the long time-to-result of pre-enrichment methods (between 24 and $36 \mathrm{~h}$ ), the cost, and complexity of SERS and $\mathrm{PCR}^{11}$ limit their use in the early diagnosis of bacterial infections.

Conversely, photochemical reactions initiated and catalyzed by light are good candidates for bacterial detection for being fast, simple, and cheap. Among them, a cyanotype reaction is considered in the first place since employing iron-based complexes is susceptible to react with bacterial components, i.e., ferricyanide and ammonium ferric citrate. In cyanotype, UV light is used to photoactivate ammonium ferric citrate, which reacts with ferricyanide to produce Prussian Blue (PB) particles and an intense blue color. ${ }^{12}$ The mechanism of the reaction entails two main steps (Figure 1, left): (i) the photochemical dissociation of iron citrate complexes, involving the reduction of iron(III) to iron(II) and the concomitant oxidation of citrate; ${ }^{13}$ and (ii) the reaction of free iron(II) ions with ferricyanide to produce $\mathrm{PB}$. It is widely accepted that citrate oxidation starts with the formation of a highly reactive citrate radical intermediate. Since poorly stable, citrate radicals

Received: August 5, 2021

Accepted: December 6, 2021

Published: December 21, 2021

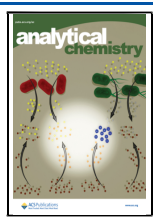




\section{Classical Cyanotype reaction}

(i) $\mathrm{Fe}\left(\right.$ III)-Cit $\stackrel{\mathrm{C}_{h v}}{\longrightarrow} \mathrm{Fe}^{2+}+\mathrm{R}_{2}^{\prime} \mathrm{C}=\mathrm{O}+3 \mathrm{CO}_{2}+2 \mathrm{H}^{+}$

$$
\text { C }
$$

\section{Cyanotype-based Bacterial Detection}

$$
\begin{aligned}
& \text { (i) } \mathrm{Fe}\left(\text { III)(Cit) } \underset{\mathrm{r}}{\stackrel{\mathrm{C}}{\longrightarrow}} \mathrm{Fe}^{2+} / \mathrm{Fe}^{3+} / \mathrm{CO}_{2} / \mathrm{H}^{+} / \mathrm{MP}\right.
\end{aligned}
$$

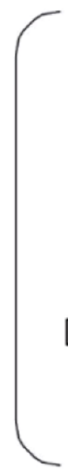

$$
\begin{aligned}
& \mathrm{Fe}(\mathrm{III})-\mathrm{Cit} \longrightarrow[\mathrm{Fe}(\mathrm{III})-\mathrm{Cit}]^{*} \\
& {[\mathrm{Fe}(\mathrm{III})-\mathrm{Cit}]^{*} \stackrel{h v}{\longrightarrow} \mathrm{Fe}^{2+}+\mathrm{Cit} \cdot} \\
& \mathrm{Cit}^{\cdot} \longrightarrow \cdot{ }^{\cdot} \mathrm{OH}-\mathrm{CR}_{2} / \mathrm{CO}_{2} / \mathrm{O}_{2}{ }^{-\bullet} / \mathrm{R}_{2} \mathrm{C}=\mathrm{O} / \mathrm{H}^{+} \\
& \mathrm{O}_{2}^{-\bullet}+2 \mathrm{H}^{+} \longrightarrow \mathrm{H}_{2} \mathrm{O}_{2}+\mathrm{O}_{2} \\
& \mathrm{OH}-\mathrm{CR}_{2}+\mathrm{Fe}^{3+} \longrightarrow \mathrm{R}_{2} \mathrm{C}=\mathrm{O}+\mathrm{H}^{+}+\mathrm{Fe}^{2+} \\
& \mathrm{H}_{2} \mathrm{O}_{2}+\mathrm{Fe}^{2+} \longrightarrow \mathrm{Fe}^{3+}+\cdot \mathrm{OH}+{ }^{-} \mathrm{OH} \\
& {[\mathrm{Fe}(\mathrm{III})-\mathrm{Cit}]^{*}+\mathrm{O}_{2}^{-*} \longrightarrow \mathrm{Fe}^{3+}+\mathrm{Cit}^{*}+\mathrm{O}_{2}} \\
& \mathrm{Cit}^{\cdot} \stackrel{\mathrm{MP}}{\longrightarrow} \mathrm{MP} \\
& {\left[\mathrm{Fe}(\mathrm{III})(\mathrm{CN})_{6}\right]^{3-} \longrightarrow\left[\mathrm{Fe}(\mathrm{II})(\mathrm{CN})_{6}\right]^{4-}}
\end{aligned}
$$

(ii) $\mathrm{Fe}^{2+}+\left[\mathrm{Fe}(\mathrm{III})(\mathrm{CN})_{6}\right]^{3-} \longrightarrow \mathrm{Fe}(\mathrm{III})\left[\mathrm{Fe}(\mathrm{II})\left(\mathrm{CN}_{6}\right)\right]^{-}$ Cit $=\mathrm{C}(\mathrm{OH})(\mathrm{COOH})\left(\mathrm{CH}_{2} \mathrm{COOH}\right)_{2} \quad \mathbf{R}=-\mathrm{CH}_{2} \mathrm{COOH} \quad \mathbf{R}^{\prime}=-\mathrm{CH}_{3}$

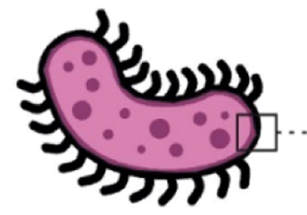

[Fe(III)-Cit $]^{*}=$ excited intermediated state SDH: succinate dehydrogenase
NADHdh: NADH dehydrogenase

Cyt b: cytochrome b

ETC

( $E \mathrm{o}=0.27 \mathrm{~V}$ vs. normal hydrogen electrode, $\mathrm{NHE}$ )

Electron Transport Chain

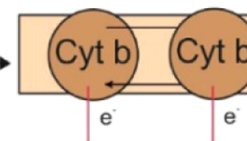

$\mathrm{Fe}(\mathrm{III})-\mathrm{Cit} \longrightarrow \mathrm{Fe}(\mathrm{III})-\mathrm{Cit}^{*}$

$\left[\mathrm{Fe}(\mathrm{III})(\mathrm{CN})_{6}\right]^{3-} \longrightarrow\left[\mathrm{Fe}(\mathrm{II})(\mathrm{CN})_{6}\right]^{4-}$

Figure 1. Illustration of the mechanism for the classic cyanotype (left) and the proposed cyanotype-based reaction for bacterial detection (right). In both cases, the mechanism is divided into two reactions, namely, (i) photodissociation of iron citrate and (ii) free iron ions' reaction with hexacyanoferrate species. Below, the main components of the electron transport chain are presented with the corresponding redox potential and role in the reaction.

dissociate rapidly to other radicals and reactive oxygen species, which react with other iron citrate molecules, accelerating their dissociation and promoting PB formation. ${ }^{14}$ This photocatalytic and radical mechanism makes the reaction very fast and promising for biosensing, but the need for UV radiation to initiate the reaction, which is toxic to bacteria, limits its application to bacterial detection.

In this work, a cyanotype reaction is modified in a way that UV light is substituted by less energetic visible light and coupled to bacterial metabolism for sensitive and selective detection of live bacteria.

\section{MATERIALS AND METHODS}

Reagents. The precursor reagents for the cyanotype-based reaction were composed of ammonium ferric citrate (Sigma Aldrich) and potassium hexacyanoferrate (Sigma Aldrich). A precursor solution was prepared in Mueller Hinton (MH) media (Sigma Aldrich) and adjusted to an acidic $\mathrm{pH}$ of 6.5 to avoid PB decomposition.

Bacterial Culture. E. coli (ATCC 25922) was donated by Prof. Herman Goossens from the University of Antwerp. Bacteria were grown overnight on an LB agar plate at $37^{\circ} \mathrm{C}$, plated using the standard streaking method. These streaks were taken from plated culture, stored at $4{ }^{\circ} \mathrm{C}$ in the fridge for a maximum of 2 weeks.
Preparation of McFarland Standard and Bacterial Samples. The McFarland standards are employed to standardize antimicrobial susceptibility tests. The optical density of these standards is used as a reference to adjust the turbidity of bacterial suspensions used in the assay. In this case, bacterial colonies were inoculated into a sterile saline solution $(0.85 \% \mathrm{NaCl} \mathrm{w} / \mathrm{v}$ in water) using a cotton swab to obtain an optical density of $0.1 \mathrm{au}$ at $600 \mathrm{~nm}$, which corresponds to the microbiology standard McFarland standard no. 0.5. The bacterial culture was prepared to match the same optical density, 0.160 for this device, which corresponded to $10^{8}$ $\mathrm{CFU} / \mathrm{mL}$ of bacteria. To adjust bacterial counts to the experiment of interest, the $0.5 \mathrm{McF}$ arland solution was diluted in an $\mathrm{MH}$ medium. The optical density of the $0.5 \mathrm{McF}$ arland standard was determined using a spectrophotometer (Smartspec Plus spectrophotometer, Bio-Rad, California).

Cyanotype-Based Assays for Bacterial Detection. The assays for bacterial detection using the cyanotype reaction were based on the standard broth microdilution protocol defined by the European Committee on Antimicrobial Susceptibility Testing (EUCAST), with the small variations detailed below resulting from the photocatalytic nature of the detection reaction. The assays were performed in 96-well plates (Cell culture microplate 96 well, PS, U-bottom, Cellstar), with the optical measurements carried out using a microplate reader 


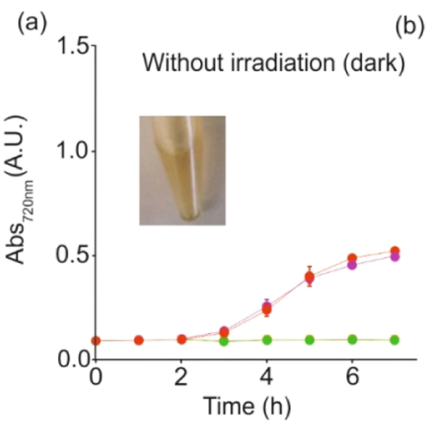

(b)

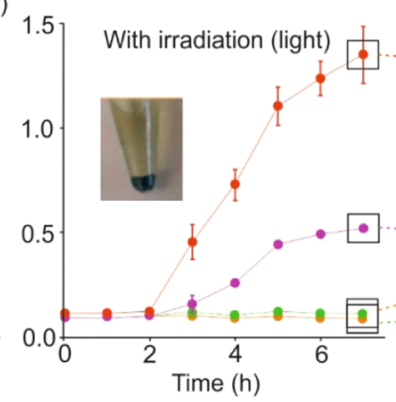

(c)
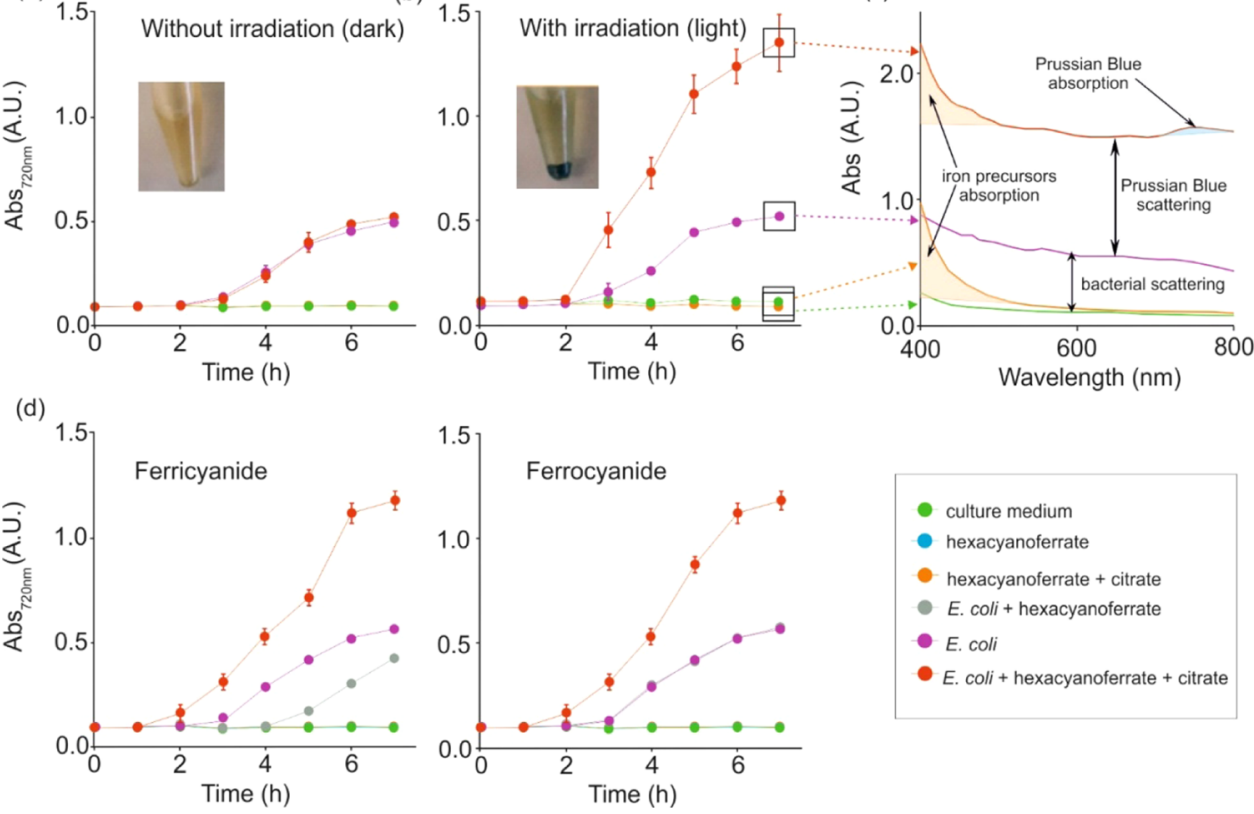

$$
\begin{aligned}
& \text { culture medium } \\
& \text { - hexacyanoferrate } \\
& \text { - } \text { E. coxacyanoferrate + citrate } \\
& \text { E. coli } \\
& \text { - E. coli + hexacyanoferrate }
\end{aligned}
$$

$$
\text { (n) }
$$


formation of a complex with an intense purple color and absorbance at $565 \mathrm{~nm}$. Complex formation has not been observed in any of the previous reaction conditions. The reason for this may be a fast reaction kinetic between free iron(III) and hexacyanoferrate ions to form PB and thus, a short lifetime of free iron ions. In addition, the lack of a reaction between ferrocyanide and iron citrate in light conditions (Figure $2 \mathrm{~d}$, orange line in the ferrocyanide plot), which should produce $\mathrm{PB}$ directly through the classical cyanotype reaction, confirms the slow kinetics of the photochemical dissociation of iron citrate molecules with visible light.

Considering previous results, the reaction mechanism presented in Figure 1 right is proposed. It involves the diffusion of iron citrate into the periplasmic region of bacteria, where it is excited to an intermediate state $[\mathrm{Fe}(\mathrm{III})-\mathrm{Cit}]^{\circ}$ by proteins and mediators of the bacterial ETC, e.g., cytochromes and ubiquinone. Thus, the intermediate formation requires intact bacterial membranes, so the presence of viable bacteria starts the reaction. This excited intermediate is susceptible to photochemical dissociation by visible light, releasing iron(II) ions and other radical intermediates, resulting from the photooxidation of citrate to the medium. Once dissociated, a photocatalytic cascade begins, where radicals react with other iron citrate molecules inducing their dissociation. Part of the iron(II) ions are reoxidized to iron(III) by the effect of the radicals and hydrogen peroxide produced as side products by the reaction. Bacterial metabolism additionally reduces intermediate iron compounds, metabolizes citrate, and reduces ferricyanide to ferrocyanide. Therefore, independently of the initial composition of the cyanotype precursor solution, the photometabolic activation of the reagents results in a mixture of free iron(II) and iron(III) ions, ferricyanide and ferrocyanide, resulting in the fast formation of $\mathrm{PB}$ molecules.

This photometabolic activation only takes place when using diluted cyanotype precursor solutions containing iron citrate concentrations below $10 \mathrm{mM}$ and maintaining a molar ratio citrate:hexacyanoferrate in the range between 4 and 8 (Figure 3a; above $10 \mathrm{mM}$ iron citrate, a classical cyanotype reaction occurs, where PB is formed spontaneously without the need for bacteria). From all combinations under study, the proportion 2.5:0.62 $\mathrm{mM}$ iron citrate:hexacyanoferrate presents the highest signal-to-noise ratio for being the one with the lowest background noise, which corresponds to the signal of the control samples without bacteria (Figure $3 \mathrm{~b}$; the absorbance magnitude and spectra of all conditions are presented in the Supporting Information, S3).

When the photometabolic reaction is conducted at different bacterial concentrations (Figure $4 \mathrm{~b}$ ), high signal amplification is obtained in all samples. A particular behavior is observed in samples below $10^{5} \mathrm{CFU} / \mathrm{mL}$, where bacterial activity is slower than photocatalysis. In this case, a sudden increase in absorbance resulting from PB formation is reported within 3 $\mathrm{h}$ of the reaction, followed by stabilization and a second increase attributed to bacterial scattering.

This fast $\mathrm{PB}$ formation is independent of the bacterial concentration for samples below $10^{5} \mathrm{CFU} / \mathrm{mL}$ and selective since it only happens in light samples containing bacteria and not in the dark ones (Figure 4a) or controls without bacteria. Therefore, the photocatalytic reaction is much faster than bacterial metabolism, which is in agreement with the mechanism proposed in Figure 1 right. That is, bacteria initiate the reaction but, after that, the light becomes (a)

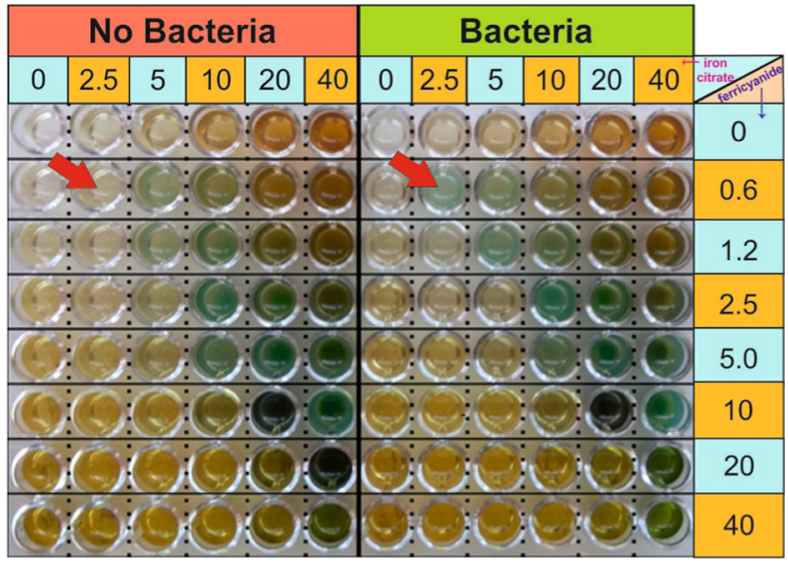

(b)

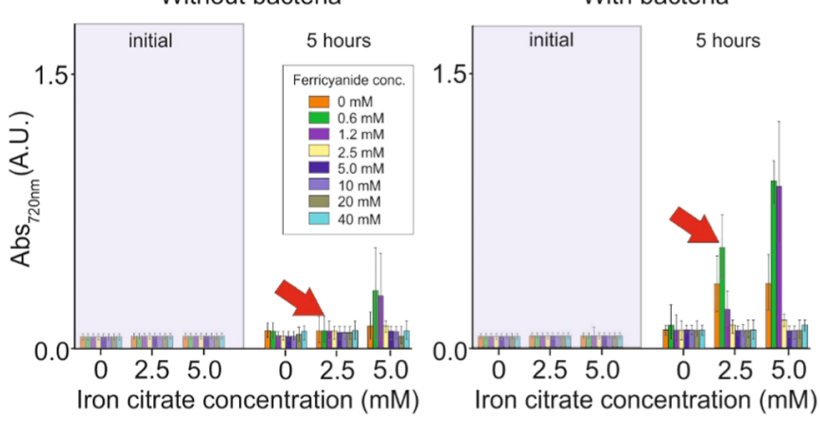

Figure 3. Optimization of the composition of the cyanotype precursor solution. (a) Image illustrating the color of the reaction solution after $5 \mathrm{~h}$ of incubation with several precursor solutions dilutions and reagents proportions. The absorbance magnitude of the most representative samples is illustrated in (b). Red arrows indicate the difference between the control sample without bacteria and the sample containing $5 \times 10^{5} \mathrm{CFU} / \mathrm{mL}$ E. coli ATCC 25922 for the concentration and proportions considered optimal $(n=3)$.

responsible to produce $\mathrm{Cit}^{\circ}$, other radicals, and reactive oxygen species in a cascade reaction, resulting in the production of free iron ions and PB molecules. This reaction takes place in $3 \mathrm{~h}$ in samples' containing bacterial concentrations as low as $100 \mathrm{CFU} / \mathrm{mL}$, which correspond to an average of $10 \mathrm{CFUs}$ for $100 \mu \mathrm{L}$ of samples. The assay, however, reaches single bacterium sensitivity and is highly repetitive, as shown in Figure 4c. In the figure, samples are grouped according to the initial bacterial concentration in (i) low bacteria (between 1 and 2 CFUs), (ii) middle (between 5 and 8 CFUs), and (iii) high (above 10 CFUs). It is clear from the results that one to two bacterial cells are not enough to induce bacterial proliferation since the second absorbance increase associated with bacterial scattering is absent in this case. Control samples without bacteria or containing dead bacteria do not present the initial sudden increase, confirming that this is a photometabolic process only happening when live bacteria are present at the initial stages of the reaction (even if they die afterward). However, the control without bacteria is not completely flat but presents some increase that may be due to some late reaction between precursor components (after 11 h) to produce PB (e.g., direct cyanotype reaction). The cyanotype-based reaction has no cross-reactivity with components present in the serum, and blood (Supporting Information, S4) since there is no PB formation in those serum/blood samples that do not contain bacteria. However, 

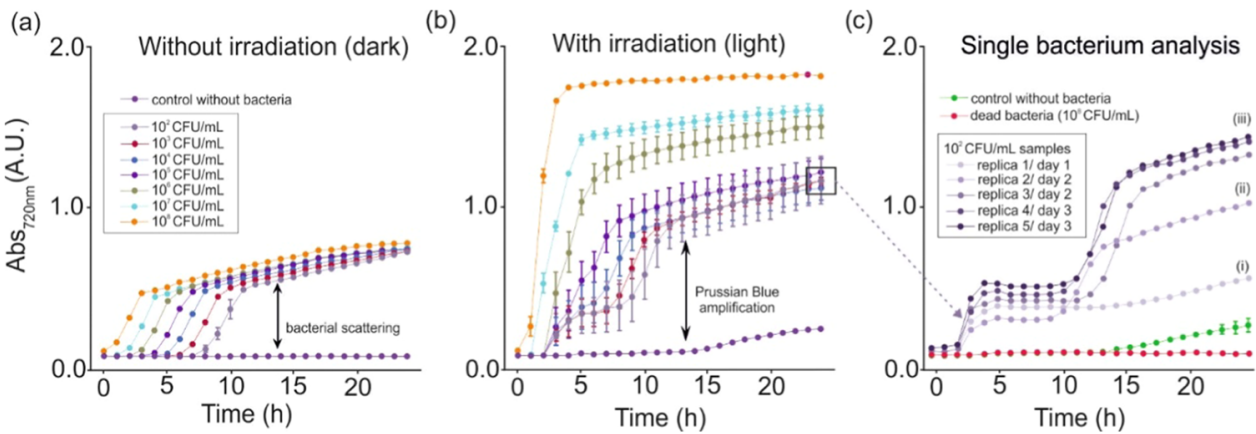

Figure 4. Evaluation of the response of the cyanotype-based reaction with different bacterial concentrations. Variation of the absorbance magnitude at $720 \mathrm{~nm}$ for samples containing cyanotype precursor solutions and bacteria at concentrations between 100 and $10^{8} \mathrm{CFU} / \mathrm{mL}$ in the dark (a) or after $5 \mathrm{~h}$ of continuous irradiation (b) $(n=3)$. In (c), the replicas of the $100 \mathrm{CFU} / \mathrm{mL}$ sample are represented individually to evaluate the variability in the single bacterium detection and compared to controls without bacteria and with dead bacteria.

the reaction in these complex matrices requires the optimization of the composition of the precursor solution to be able to detect $\mathrm{PB}$ formation within $3 \mathrm{~h}$ (now requiring $5 \mathrm{~h}$ for $10^{2} \mathrm{CFU} / \mathrm{mL}$ samples). It is important to remark that the photochemical reaction has been demonstrated for $E$. coli, which is used as a model microorganism. However, proteins and redox mediators present in the ETC are very conservative between bacterial species, and such a reaction should be applicable to a wide number of Gram-positive and Gramnegative bacteria. In this sense, the reaction has been already demonstrated by the Gram-positive microorganism Staphylococcus aureus in a recent article of the group focused on sepsis diagnostics. ${ }^{23}$

\section{CONCLUSIONS}

In summary, the substitution of UV by visible light in a cyanotype photochemical reaction enables the coupling of $\mathrm{PB}$ formation to bacterial metabolism. The reaction mechanism involves the photoactivation of iron citrate molecules into an excited intermediate state by reactive components in the electron transport chain, which is susceptible to photoactivation with visible light to produce free iron ions and citrate radicals. Iron ions react with hexacyanoferrate molecules to produce $\mathrm{PB}$ particles in less than $3 \mathrm{~h}$, a process catalyzed by citrate radicals that initiate a cascade reaction with other iron citrate molecules to produce more radicals and free iron ions. The reaction is very selective, requiring the presence of light and bacteria, and sensitive since it may be activated by a single microorganism. Components of complex biological fluids such as serum or blood do not present cross-reactivity with the reaction precursors, making it possible to detect very low bacterial concentrations in a short time and without sample pretreatment. The simplicity, selectivity, and short time-toresult of this photometabolic reaction are envisioned to have an impact on clinical diagnosis of bacterial infections, in particular in sepsis diagnostics where early detection of bacteria in the bloodstream is fundamental to improve the prognosis of the pathology. This protocol may be also used for fast antibiotic susceptibility testing, the determination of minimal inhibitory concentration, and the identification of resistant bacteria.

\section{ASSOCIATED CONTENT}

\section{(s) Supporting Information}

The Supporting Information is available free of charge at https://pubs.acs.org/doi/10.1021/acs.analchem.1c03326.
Additional experiments for the evaluation of the role of cyanotype precursors in the reaction (S1); additional experiments for the evaluation of the presence of free iron(III) molecules during the cyanotype-based reaction (S2); additional experiments to study the proportion and concentration of the precursor solution components (S3); additional experiments to evaluate the crossreactivity of the cyanotype-based reagent with serum and blood components (S4) (PDF)

\section{AUTHOR INFORMATION}

\section{Corresponding Authors}

Gonzalo Guirado - Departament de Química, Universitat Autònoma de Barcelona, Bellaterra (Barcelona) 08193, Spain; 이이이.org/0000-0003-2128-7007; Email: Gonzalo.Guirado@uab.cat

Xavier Muñoz-Berbel - Instituto de Microelectrónica de Barcelona (IMB-CNM, CSIC), Bellaterra (Barcelona) 08193, Spain; (o orcid.org/0000-0002-6447-5756; Email: xavier.munoz@imb-cnm.csic.es

\section{Authors}

Jiri Dietvorst - Instituto de Microelectrónica de Barcelona (IMB-CNM, CSIC), Bellaterra (Barcelona) 08193, Spain; Nanobiotechnology for diagnostics (Nb4D), Department of Chemical and Biomolecular Nanotechnology, Institute for Advanced Chemistry of Catalonia (IQAC, CSIC), Barcelona 08034, Spain

Amparo Ferrer-Vilanova - Instituto de Microelectrónica de Barcelona (IMB-CNM, CSIC), Bellaterra (Barcelona) 08193, Spain; Departament de Química, Universitat Autònoma de Barcelona, Bellaterra (Barcelona) 08193, Spain; 이이이.org/0000-0002-4223-8442

Sharath Narayana Iyengar - Division of Nanobiotechnology, Department of Protein Science, Science for life laboratory, KTH Royal Institute of Technology, Stockholm 17165, Sweden; orcid.org/0000-0001-5348-3526

Aman Russom - Division of Nanobiotechnology, Department of Protein Science, Science for life laboratory, KTH Royal Institute of Technology, Stockholm 17165, Sweden

Núria Vigués - Departament of Genetics and Microbiology, Universitat Autonoma de Barcelona, Bellaterra (Barcelona) 08193, Spain

Jordi Mas - Departament of Genetics and Microbiology, Universitat Autònoma de Barcelona, Bellaterra (Barcelona) 08193, Spain 
Lluïsa Vilaplana - Nanobiotechnology for diagnostics (Nb4D), Department of Chemical and Biomolecular Nanotechnology, Institute for Advanced Chemistry of Catalonia (IQAC, CSIC), Barcelona 08034, Spain; CIBER de Bioingeniería, Biomateriales y Nanomedicina (CIBER$B B N)$, Barcelona 08034, Spain

Maria-Pilar Marco - Nanobiotechnology for diagnostics (Nb4D), Department of Chemical and Biomolecular Nanotechnology, Institute for Advanced Chemistry of Catalonia (IQAC, CSIC), Barcelona 08034, Spain; CIBER de Bioingeniería, Biomateriales y Nanomedicina (CIBER$B B N)$, Barcelona 08034, Spain; 다이.org/0000-00024064-1668

Complete contact information is available at:

https://pubs.acs.org/10.1021/acs.analchem.1c03326

\section{Notes}

The authors declare no competing financial interest.

\section{ACKNOWLEDGMENTS}

This project has received funding from the European Union Horizon 2020 Research and Innovation Programme under the Marie Skłodow-ska-Curie grant agreement no. 675412 as a part of the consortium New Diagnostics for Infectious Diseases (ND4ID). G.G. thanks the Ministerio de Ciencia e Innovación of Spain for financial support through the project PID2019106171RB-I00. Patent (P42106384SE00) based on part of this work was granted. M.-P.M. and L.V. would like to thank the Ministry of Science and Innovation (SAF2015-67476-R and RTI2018-096278-B-C21) and Fundación Marató de TV3 (TV32018-201825-30-31).

\section{REFERENCES}

(1) Vouga, M.; Greub, G. Clin. Microbiol. Infect. 2016, 22, 12-21.

(2) Abou Zeid, A. A.; El Sherbeeny, M. R. Zentralblatt Bakteriol. Parasitenkd. Infekt. Hyg. Zweite Abteilung 1975, 130, 314-333.

(3) Cabral, J. P. S. Water Microbiology. Bacterial Pathogens and Water. In International Journal of Environmental Research and Public Health; Molecular Diversity Preservation International, Oct 15, 2010; pp 3657-3703.

(4) The top 10 causes of death. https://www.who.int/news-room/ fact-sheets/detail/the-top-10-causes-of-death (accessed Jun 22, 2021).

(5) Food safety. https://www.who.int/news-room/fact-sheets/ detail/food-safety (accessed Jun 22, 2021).

(6) Yagupsky, P.; Nolte, F. S. Clin. Microbiol. Rev. 1990, 3, 269-279.

(7) Kumar, A.; Roberts, D.; Wood, K. E.; Light, B.; Parrillo, J. E.; Sharma, S.; Suppes, R.; Feinstein, D.; Zanotti, S.; Taiberg, L.; Gurka, D.; Kumar, A.; Cheang, M. Crit. Care Med. 2006, 34, 1589-1596.

(8) Roszak, D. B.; Colwell, R. R. Appl. Environ. Microbiol. 1987, 53, 2889-2893.

(9) Brakstad, O. G.; Aasbakk, K.; Maeland, J. A. J. Clin. Microbiol. 1992, 30, 1654-1660.

(10) Lin, H.-Y.; Huang, C.-H.; Hsieh, W.-H.; Liu, L.-H.; Lin, Y.-C.; Chu, C.-C.; Wang, S.-T.; Kuo, I.-T.; Chau, L.-K.; Yang, C.-Y. Small 2014, 10, 4700-4710.

(11) Sinha, M.; Jupe, J.; Mack, H.; Coleman, T. P.; Lawrence, S. M.; Fraley, S. I. Emerging Technologies for Molecular Diagnosis of Sepsis. In Clinical Microbiology Reviews; American Society for Microbiology, April 1, 2018.

(12) Lawrence, G. D.; Fishelson, S. J. Chem. Educ. 1999, 76, No. 1216A.

(13) Feng, W.; Nansheng, D. Chemosphere 2000, 41, 1137-1147.

(14) Seraghni, N.; Belattar, S.; Mameri, Y.; Debbache, N.; Sehili, T. Int. J. Photoenergy 2012, 2012, 1-10.
(15) Pujol-Vila, F.; Vigués, N.; Guerrero-Navarro, A.; Jiménez, S.; Gómez, D.; Fernández, M.; Bori, J.; Vallès, B.; Riva, M. C.; MuñozBerbel, X.; Mas, J. Anal. Chim. Acta 2016, 910, 60-67.

(16) Pujol-Vila, F.; Giménez-Gómez, P.; Santamaria, N.; Antúnez, B.; Vigués, N.; Díaz-González, M.; Jiménez-Jorquera, C.; Mas, J.; Sacristán, J.; Muñoz-Berbel, X. Sens. Actuators, B 2016, 222, 55-62.

(17) Pujol-Vila, F.; Dietvorst, J.; Gall-Mas, L.; Díaz-González, M.; Vigués, N.; Mas, J.; Muñoz-Berbel, X. J. Colloid Interface Sci. 2018, 511, 251-258.

(18) Lall, N.; Henley-Smith, C. J.; De Canha, M. N.; Oosthuizen, C. B.; Berrington, D. Int. J. Microbiol. 2013, 2013, 1-5.

(19) Ferrer-Vilanova, A.; Alonso, Y.; Dietvorst, J.; Pérez-Montero, M.; Rodríguez-Rodríguez, R.; Ivanova, K.; Tzanov, T.; Vigués, N.; Mas, J.; Guirado, G.; Muñoz-Berbel, X. Ultrason. Sonochem. 2021, 70, No. 105317.

(20) Wagegg, W.; Braun, V. J. Bacteriol. 1981, 145, 156-163.

(21) Mahren, S.; Schnell, H.; Braun, V. Arch. Microbiol. 2005, 184, $175-186$.

(22) Frawley, E. R.; Fang, F. C. The Ins and Outs of Bacterial Iron Metabolism. In Molecular Microbiology; Blackwell Publishing Ltd., Aug 1, 2014; pp 609-616.

(23) Iyengar, S. N.; Dietvorst, J.; Ferrer-Vilanova, A.; Guirado, G.; Muñoz-Berbel, X.; Russom, A. ACS Sens. 2021, 6, 3357-3366.

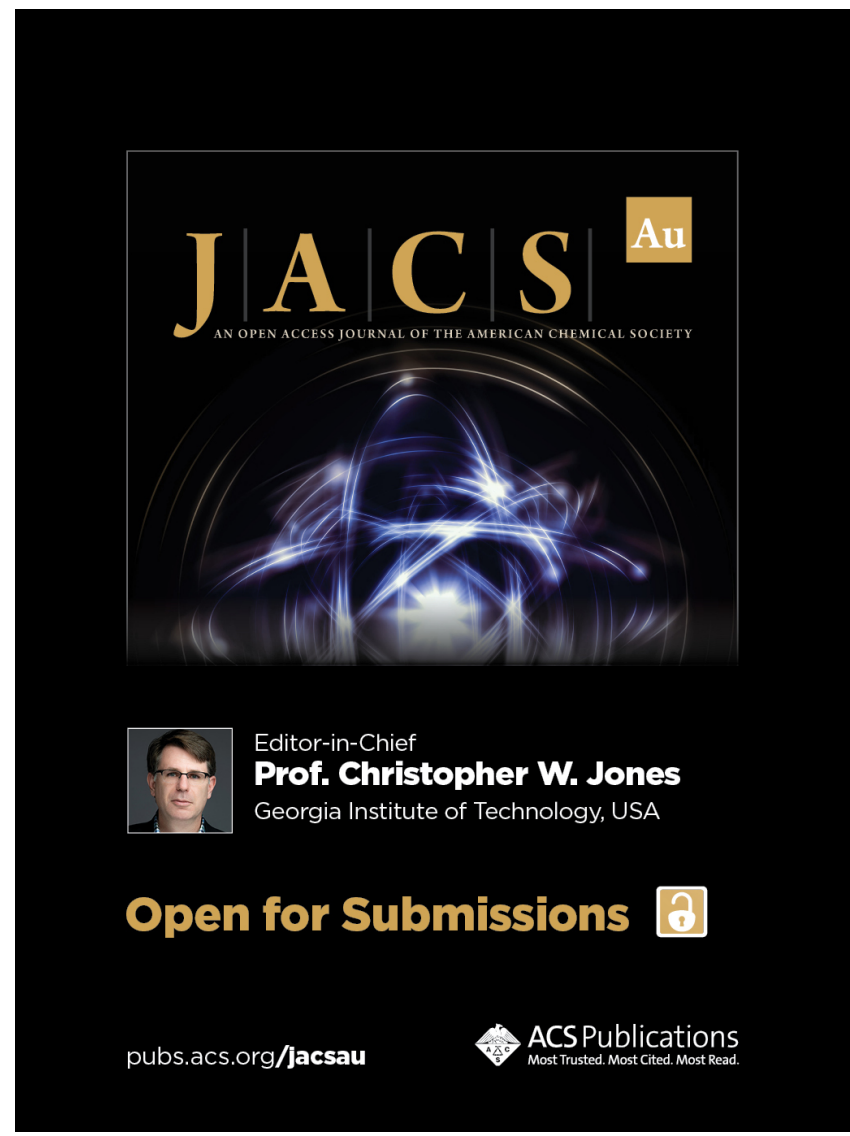

